\title{
Arte de governar
}

João Arruda

\author{
Advertencia preliminar
}

No isolamento em que me acho, medito constantemente sobre a tragedia que abala hoje a humanidade. Nessas reflexões, quasi torturado por uma idéia fixa, julguei ser de interesse a publicação de minha opinião acerca da dificuldade de explicar esses fenômenos sociais em que todos, ou quasi todos os homens, se julgam com direito de emitir sua opinião, e prognosticar venturas ou desventuras para o mundo culto, para os povos civilizados. Castelo Branco denominou seus trabalhos, filhos de elocubrações durante suas vigilias, "Noites de Insonia". Si parva licet componere magnis, eu poderia denominar esse meu modesto trabalho "Dias de Soledade". Não julgue o leitor que eu seja da opinião geral da imprensa, quando diz que, antes dessa grande tragedia anglogermanica, nada houve na Historia que com ela se possa comparar. Escusavel é esse modo de ver da imprensa, considerando-se que Tucydides supunha que, antes de seu tempo, nada de importante tinha havido no mundo. Para mim a tragedia de nossos dias em nada é mais tremenda, horrivel, medonha do que as narradas na Biblia, notadamente no livro de Josué. Não é mais horrivel que a invasão da Europa pelos Hunos, a guerra de cem anos, etc.

A luta anglo-germanica é um episodio muito conhecido na vida da humanidade, e as crueldades de que somos hoje testemunhas em nada superior às torturas inventadas pela Inquisição, deparando-se-nos em Torquemada homem tão 
cruel quanto Hitler, e encontrado, nos atuais inventores de suplicios, êmulos de Nero e de Josué, e mesmo dos conquistadores do Novo Mundo: espanhóis, portugueses e outros.

Já muitas vezes tenho citado, em meus anteriores trabalhos, o artigo de celebre escritor e sociólogo italiano AcHILLES LORIA: "Siammo noi megliori dei nostri antenati?" O grande sociólogo responde pela negativa. Nega tenhamos melhorado organicamente. Ha pouco, em revista de data recentissima, vi sustentado o contrário, e este é já um dos problemas históricos dentre os muitos com que passo a ocuparme. Muito têm dito os historiadores da crueldade de Pizarro e de outros aventureiros espanhois. Pois bem! Vindo de Goiás um dos meus amigos, contou-me que era corrente lá haverem verdadeiras montanhas de ouro, um novo El Dorado, diante do qual nada representavam as minas da California, ou as de prata da Bolivia. Impossivel porém era que os homens civilizados se apoderassem destas riquezas, suficientes para pagar-se o que deve o Brasil, por estarem elas nas terras ocupadas pelos selvagens xerens. Prossigo: não houve, sinão raramente, homem civilizado a quem eu repetisse o que ouvi de meu amigo que não tivesse a idéa de proceder com os selvagens como procediam Pizarro e outros aventureiros... PiErre VAn PAassen refere-nos, na sua recente e conhecidissima obra "Estes Dias Tumultuosos", atos de crueldade que em nada são menos horriveis que os do tempo da Inquisição, ou de Josué. Mostra que, ainda hoje, os Neros imaginosos procuram inventar suplicios que impressionem o povo: as tochas vivas de Roma, os suplicios infligidos pelos Cartagineses a Regulo, os cremadores de Torquemada são rivalizados pelas novas torturas, si não por estas superados!..

Não vou tratar sómente (seja desde já advertido) com o que sucede neste trágico momento da vida dos povos, mas tambem com o que se deve fazer em tempos normais para que os homens sejam menos infelizes: ut beati degant vitan.

Ao ler as notícias sobre as medidas tomadas pelos dirigentes dos povos mais cultos acerca da atual guerra, lem- 
bro-me sempre da frase de Oxenstienr Nescis, mi fili, quantilla prudentia homines reguntur: é esta minha opinião, e todos sabem quanto vale a das pessoas que se acham fora da agitação de um pleito, e é tambem o modo de pensar de muitos entendidos, que mostram (sempre tratando dos erros dos adversarios) as descambadelas em que caíram aqueles a quem foi dado o leme do govêrno dos paises ora em crise. Antes de fazer referencia aos problemas sociais, seja-me facultado dizer, na minha opinião, qual o campo em que se desenvolvem as diversas ciências que se ocupam com as forças que regem o movimento histórico dos povos. Em seguida, mostrarei que bem poderia ter tomado para titulo destas minhas meditações, à imitação de Alexis Carrel o "Organismo Social, este desconhecido",

\section{CIÊNCIAS E ARTES SOCIAIS}

Para mim, é o Direito Administrativo a ciência que se desenvolve na aplicação das leis positivas sobre a administração, sendo lícito ao aplicador recorrer aos costumes, à interpretação, à doutrina dos mestres e a outros subsidios, como sucede nas ciências jurídicas. A Ciência e a Arte de Administrar, segundo creio, estão intimamente ligadas, de modo a ser impossivel separar uma da outra, donde até serem denominados esses ramos dos conhecimentos humanos ciências práticas. E' o que sucede com a Política que opera sobre fatos tão intimamente ligados com a direção da sociedade que impossivel será, na generalidade dos casos, dizer onde acaba a afirmação científica de uma lei natural, e onde começa a arte de dirigir as forças do organismo social. Julgo que a Sociologia ocupa-se com as leis que presidem a origem, o desenvolvimento e o desaparecimento das sociedades. Indagar como atua o instinto gregario, se ha em todas as sociedades a tendencia ao progresso, ou se este é uma exceção, investigar quais os povos mais felizes, e qual o fim que devem propor-se os governos para que haja o bem estar para a maioria dos membros da comunhão, definir em que 
consiste o progresso, etc., eis os assuntos com que me parece ocupar-se a Sociologia. Entre a Política e a Sociologia creio haver uma diferença. A Política só aparece quando tem de estudar o modo por que um governo deve procurar dirigir a vida de uma sociedade.

Quando Hartmann estudava os povos da Africa, quando Hermann Post nos dava conta da vida dos povos selvagens, quando Southey narrava o que era a sociedade dos selvagens sulamericanos, estavam, segundo me parece, ocupando-se com a Sociologia. Quando, organizado um povo sob um governo, mais ou menos regular, deve ser dirigido por meios artisticos, opondo o governo uma força a outras, para, com um mínimo de resistencia, alcançar o fim a que se propõe, ou que julga mais util para a comunhão, ha recurso às regras da Política, que, na forma científica, estuda as forças sociais, e, na artistica, procura dirigí-las. $O$ entrelaçamento dos fenomenos sociais, o que se denomina o consensus, eis o que impede de traçar uma linha nitida divisoria entre os campos destes estudos artisticos ou cientificos. Passo a mostrar quão árduos são os problemas que se deparam aos governantes de uma sociedade. Já se disse, e se repetiu, um sem número de vezes, que, quando nosso relogio se desarranja, procuramos um técnico versado na dificil arte da relojoaria. Quando porém ha uma crise, por mais grave que seja, no organismo social, que não se póde comparar em complexidade com o maquinismo de um relogio, julga-se qualquer sarrafaçal em condições de dar remédio ao mal... Conhecer, no limite do possivel, quais as forças do organismo social, saber com que elementos deve contar o governante, poder dizer qual a psicologia do povo, estar bem esclarecido sobre as tendencias dos governados, saber quais as condições economicas religiosas e outras dos governados, eis alguns dos elementos com que póde manejar o governante. Si ha povos guerreiros, que julgam ser a industria da guerra a que lhes deve ser facultada, e até facilitada por meio de uma educação belicosa, procurar coibir sem violencia vicios perigosissimos para a virilidade do povo, como é o do uso 
dos entorpecentes, evitar o fanatismo, sem ferir as crenças dos individuos, opôr, em suma, forças a forças, em prol da sociedade, é o dever do bom politico, do governo que se interessa pelo povo. Suponho assim um govêrno exemplar, e não o que, em geral, existe ha humanidade: o que só cogita do proprio interesse, a pretexto de tutelar o povo para felicidade deste.

Falo, seja bem claro, em teoria, buscando o que é aconselhado por quem verdadeiramente com altruismo, quer a felicidade da maioria, o bem estar social.

\section{UM INCIDENTE}

Estas minhas últimas palavras levam-me ao exame de assunto que me parece de suma utilidade para meu escopo neste artigo. Refiro-me à boa fé dos governantes. Tem-se muitas vezes dito que o bom déspota é um ente de imaginação, uma figura impossivel em nossa mísera humanidade de capacidade limitadissima. Mostra-se que por mais culto que seja um homem, incapaz é de compreender todos os segredos do orgasismo social (materia principal neste meu estudo), e de descobrir os remédios a serem dados aos males de um grupo humano. Na penumbra se deixa a má fé de quasi todos os governantes. Estuda-se a parte intelectual, mas. não a moral, os dotes intelectuais do chefe, mas não sua moralidade, seu amor ao povo, seu altruismo... Apresentarei um símile. Costumam os professores de Historia, para conhecerem e apurarem a sagacidade de seus discípulos, perguntar-lhes quais os pretextos e quais as verdadeiras razões ou reais motivos das guerras que encontram narradas em seus compendios. E' o que na giria moderna se denomina um test: isto não tem importancia para meu atual estudo. O mesmo porém que se diz das guerras pode ser dito da legislação e das medidas administrativas, e é o que agora me interessa. Para a legislação é típico o caso da permissão de casamento entre tio e sobrinha no tempo do imperador Adriano. Para tipo das medidas administrativas, ha o caso. 
do desarmamento da plebe a pretexto de diminuição de crimes, mas por medo de revoltas contra o governo. Não ha necessidade de ser um Metternich, um Talleyrand, para perceber que a Casa da Austria, a dinastia dos Habsburgos, a familia Hohenzollen, a casa de Saboia, em todos seus atos (leis ou medidas administrativas) deveriam ter em mira mais seu proprio interesse que os de seu povo: todos sabem o que é o egoismo. Mas o que geralmente se ignora, ou se deixa em esquecimento é que Francia, Rosas, Melgarejo, Gomez, o tirano dos Andes e outros déspotas sulamericanos, do mesmo modo que Cromwell, os Bonapartes só tinham o cuidado de assegurar suas vantagens e a de seus parentes e membros de sua grei, de seus apaniguados ou sustentaculos.

$\mathrm{O}$ que acabo de dizer em relação às casas reinantes, aos usurpadores e às familias e protegidos destes e daquelas, posso tambem afirmar das metrópoles em relação às suas colonias. O que foi a Inglaterra em relação às suas colonias, dominios, todos sabemos. O que fez com os Estados Unidos, di-lo, em maviosos versos Longfellow, em sua "Evangelina". Falem tambem os boers e a India... O que nos fez Portugal, está bem em nossa memoria. Os que não lêem a Historia do Brasil narrada por escritores concienciosos, como o era Pereira da Silva, conhecem, ao menos por tradição, que Portugal só se lembrava da colonia para lhe sugar o ouro, para lhe entregar os filhos à Inquisição, para enforcar e esquartejar os que pensavam em privá-lo da explorada vítima, como fez com Tiradentes. Levava seu egoismo ao ponto de nunca ter mandado forças para lutar com os Holandeses, seguro de que o Brasil saberia, com seus bravos filhos, livrar-se do novo dominador, pior quiçá do que o português, como se tem patenteado na ilha de Java. Este é o egoismo das metrópoles, e é de lembrar que, como diz Palante, o egoismo de grupo é muito mais acentuado que o do indivíduo.

Nem deixarei estas observações incidentes sobre o egoismo de grupo sem lembrar que, desde a mais remota antiguidade de que temos noticia histórica, sabemos que de 
Atenas tinham a mesma queixa os confederados que lhe pagavam para os defender contra os inimigos externos: Atenas, com o dinheiro que dos aliados recebia, embelezava-se, e nada fazia em pról daqueles com cujo dinheiro se engrandecia.. Ainda sobre egoismo de grupo é muito significativo o que disse Chamberlain recentissimamente, quando se discutia si a Inglaterra deveria ir, ou não, em socorro da Polonia, atacada pelos alemães.

Sustentou, e seu discurso é um compendio de egoismo, que não era admissivel fosse seu país entregar-se aos horrores de uma guerra em pról de indivíduos que não conhecia!... Neste artigo só me ocupo com a Política Interna, e o que acabo de narrar é suficiente para mostrar o que é o egoismo de grupo. Quero porém, saindo do assunto principal deste artigo, mostrar o erro político inglês. Houve um egoismo mal entendido, e isto foi provado pelos fatos posteriores. Tivesse a Inglaterra entrado na guerra em defesa da Polonia no momento em que a Alemanha ainda não tinha conseguido aumentar suas forças, com o sistema de ir vencendo um a um os paises mais fracos, e não teria o imperio Britanico de arcar, mais tarde, com a tremenda luta que deveu sustentar contra a Alemanha, posteriormente fortificada pelo êrro de Chamberlain e de povos fracos europeus que não quiseram congregar-se para defesa comum.

Por vezes ainda nesta matéria ha exagero por um simplicismo do povo rude. Dizem, por exemplo, os que compõem as classes menos cultas da sociedade que as guerras têm sempre por único fator o interesse da classe capitalista. E' um êrro, conforme patentearam muitos sociólogos, e entre estes, posso apontar KreHbieL.

O que acabo de dizer sobre a boa fé do governo, ou do suposto bom déspota tem, creio eu, suma importancia, e não posso explicar porque foi deixado em penumbra pelos sociólogos. Minha estranhesa cresce de ponto quando considero que houve alguns conhecedores dos segredos da vida dos povos que afirmaram diminuir a moralidade à medida que cresce a cultura, a civilisação. E' lei que me parece não 
estar ainda verificada, mas que deveria induzir os sociólogos a estudar a psicologia do déspota por este aspecto. Postas essas bases de estudo ou exame, passo a dar noticia de problemas sociais, começando pelos mais árduos, por aqueles que nunca serão solvidos, para os quais devemos reservar o ignorabimus. São inumeros esses problemas que por sua dificuldade podem ser julgados insoluveis, e para os quais pois não podemos pedir nem mesmo paliativos.

Direi depois sobre outros problemas menos árduos, colocando no fim deste artigo os políticos.

\section{PROBLEMAS INSOLUVEIS}

São apenas do ponto de vista prático insoluveis estes problemas, porque é possivel, mas não provavel, que sejam, algum dia, solvidos. Não se podem pois comparar como o da origem das idéas na Psicologia, com a origem do movimento ou da matéria na Cosmogonia, com a explicação do motivo da existencia do mal na Teodicéa, etc.

Indicarei o primeiro, que é assunto de predileção de quasi todos os sociólogos no momento que atravessa a humanidade. Porque será que as familias aristocraticas são pouco fecundas? Os fidalgos, que pretendem hoje ser descendentes dos cruzados, têm de confessar, dizem os sociólogos, que, entre seus avós, ha seguramente algum plebeu.

As familias reais para não se extinguirem são forçadas a ligarem-se a algum fidalgo ou fidalga, assim como os fidalgos vão recorrer à plebe. E' repito, o que todos os grandes mestres, entre os quais mencionarei Mougeolle e LITTRÉ, asseveram. A gente que de tudo fala, embora sem preparo, os ignorantes audazes julgam explicar o fato pelo néo-maltusianismo. E' um despropósito, já porque o neo-maltusianismo é de recente data e peculiar a um grupo restritissimo na sociedade, quando o fenomeno, segundo os historiadores, é antigo, já, porque o fenomeno existe tambem, dizem LitTré, MougEolle e outras grandes autoridades, nos irracionais. 
Houve quem pretendesse explicar a pouca fecundidade da raça Durhan pela união in and in, como dizem os criadores ingleses, isto é, pelas uniões consanguineas. Mas em relação a outras raças bovinas, aos cavalos, às galinhas, aos cães (notadamente o "bull dog"), os gatos e outros animais domesticos o mesmo sucede. Das muitas explicações que foram apresentadas, destacarei uma que nos é noticiada por Vanni, em seus "Ensaios de Filosofia Social e Jurídica". Diz ele ter sido afirmado que, à medida que se desenvolve a cultura intelectual (seja dito o cerebro), diminúe a capacidade para a reprodução da especie. Esta explicação, que recorre à Biologia, afasta apenas a dificuldade, e tem o defeito ainda de não servir para esclarecer o que se dá com os animais.

Os partidarios de tal doutrina dizem que o enfraquecimento da natalidade em França é prova, não de decadencia, mas sim de progresso e superioridade. Fertil é o problema em ramificações secundarias.

Assim, como acima ficou dito, é fora de dúvida que os pobres, os mal nutridos são mais fecundos do que os que se fartam de alimentos, até inuteis para a manutenção da vida: o îrlandês que se alimenta de quantidade mínima de batatas, o francês das regióes pobres que supre a falta do pão pela batata, são mais fecundos do que os milionarios que se regalam em suas mesas lautas com as mais finas e substanciais iguarias. Mas a estatística tambem revelou (oh surpresa!) que os anos de colheitas abundantes são os em que é maior a natalidade.

Até deste fenomeno foi que nasceu a celebre frase de Proudhon: "Ha antagonismo entre o trabalho e o amor". VANni, nos "Ensaios" a que aludi linhas acima, Gide, em sua "Economia Política", dizem que não se deve atender sómente à quantidade (número de membros da comunhão social), mas tambem à qualidade. Fóra de dúvida é que num grupo em que é grande o número de individuos que consomem riquezas comparado com o dos produtores, a miséria é ameaçadora. Julgo porém que a influencia econômica da densi- 
dade da população pertence à Politica, e que a importancia desse fator no crime toca à Criminologia. Neste mesmo artigo ocupar-me-ei com o fenômeno da alçada da Criminologia. Farei agora referencia, embora passageira, a alguns outros fenomenos inexplicaveis. Já no conhecidissimo livro de Job, segundo muitos e autorisados investigadores o mais antigo dos da Biblia, era firmada a coragem do cavalo e a impossibilidade de ser domesticạda a zebra.

Outro tanto podemos dizer dos povos: porque são uns bravos, corajosos, e outros covardes, alguns inclinados a certas artes e outros a outras... Grave problema ainda é tambem o conhecidissimo da loucura coletiva. Deste ha soluções, mais ou menos imaginosas e sutis, fundadas em fenomenos biológicos de nenhum modo livres de contestação, como por exemplo, os dados por Campilli e Scipião Sighelle.

Antes de passar aos problemas politicos, anticipo o que me parece estar ao alcance dos governantes nos casos que acabo de mencionar: adotar medidas paliativas. Já Platão disse que o ideal não passa da realidade, corrigidos, quanto possivel, os defeitos desta.

Darei exemplo para tornar bem claro meu pensamento. Nos paises em que ha terremotos frequentes, o remédio a ser adotado é o da proibição de predios elevados. Construções térreas e de materiais leves, de modo a reduzir ao mínimo o estrago causado pelo fenômeno, eis o que é principalmente aconselhavel.

Facil me seria encher paginas e paginas com problemas, senão insoluveis, ao menos que podem ser considerados tais pela pouca probabilidade de serem algum dia, em futuro muito remoto, solvidos. Pergunta-se, por exemplo, será o progresso devido à ação dos grandes homens, como julgam Carlyle e tantos outros (hero worships), ou fruto do trabalho da multidão, como entendem Mougeolle e um grande número de sábios cultores dos estudos sociais? Pergunta-se tambem: serão mais felizes os paises de grande estensão territorial, ou os de pequena área? Os defensores desta última 
opinião dizem que os paises pequenos até para a guerra são superiores aos muito vastos. Apontam particularmente, ientre os antigos, a Grecia; e, dos modernos, a Holanda. Na Italia e na Alemanha houve, ha uns 60 anos, o movimento centrípeto, ou de unificação dos vários territorios. Este problema desenvolveu-se pacificamente entre partidos norteamericanos, mas, noutros logares, excitoú exaltações de fanáticos, como sucedeu na Argentina, onde pelas ruas o povo gritava: "muerte a los asquerosos unitarios!..." De homens de letras apontarei PIY MArgal. Houve escolas sociológicas ou políticas que podem ser denominadas harmonicas, já fixando como sendo o maximo desejavel de um território a área da França, já pelo artificio da federação ou da confederação. E' assunto tão conhecido que me julgo dispensado de dizer mais sobre ele. Ha ainda a disputa sobre qual seja a diretriz preferivel no desenvolvimento econômico: será preferivel a industria agricola ou a manufatureira, a extrativa, a fabril?... Quando um país tem ricas minas, é claro que não deverá entregar-se à agricultura, mórmente si seu solo, seu clima e outros fatores não forem propicios à cultura. O contrario se dirá quando o terreno é ubertoso, mas pobre em minas. Nem sempre porém satisfaz essa solução: o problema, por vezes, é árduo em face da exigência popular ou do capricho governamental. Recordo-me de que, em 1877, houve na Inglaterra uma grande manifestação contra o governo, que o povo julgava dar atenção demasiada às minas, à exploração do ferro e do carvão. Em uma procissão popular, em Londres, exibiam os descontentes dois pães de um mesmo preço, um de Londres e outro da Polonia: este era muito maior que aquele, quiçá duas ou três vezes. Procuravam assim os operarios mostrar quão mais felizes são os povos agricolas. No entanto recentissimamente vejo nos jornais que a nossa vizinha Argentina, de terras ubérrimas, com excelentes uvas, trigo e carne, quer se tornar manufatureira, fabril!... E, ou não, o caso de dizer que se trata de um problema de dificil solução em face dos caprichos go- 
vernamentais ou populares... Este problema é mais politico do que sociológico, no meu entender.

Entro a dar uma ligeira idéa dos problemas politicos.

\section{GRAVES PROBLEMAS POLfTICOS}

Deixando de ocupar-nos com as medidas adotadas pelos governos para aumento da população, por serem assás conhecidas, e quasi todas de completa ineficácia, bem como com as raras providencias para regularizar a densidade, providencias que se cifram em emigração e imigração, passarei a referir-me ao fenomeno da tendencia que ha para a fuga dos campos para a cidade. Como corrigir esse mal?

E' propinquo este problema do relativo à deserção dos serviços musculares para os trabalhos intelectuais. Este último, como é sabido, mesmo pelos compendios elementares de História, existiu até no Egypto dos Faraós. . e com ele se ocupa o hodierno GIDE, em sua recentissima Economia Politica... Mussolini resolveu, ou julgou resolver a dificuldade de um modo violento, ou drástico, para me servir da expressão hoje em uso: mandou afugentar a tiros de carabina os camponêses que procurassem trocar o campo pela cidade.

Outros governos mais humanos e mais sensatos adotaram muitas medidas paliativas, as unicas possiveis no caso: tornar a vida do camponez mais agradavel, dar-lhe crédito, fornecer-lhe em boas condições as ferramentas de que necessita, instruí-lo, dar-lhe meios de educar a prole, organisar núcleos onde escape do isolamento, cruel para todo homem... em ocasiões de crises no campo, ainda ha o recurso aos serviços públicos, embora dispensaveis, ou sem urgencia, como se tem feito em nosso país nos casos da calamidade que é a seca do Norte. Ainda ha, se estas medidas não derem resultados, a organisação de obras de utilidade pública, como sejam campos de cultura de vegetais uteis, de criação de animais proveitosos para a riqueza nacional e 
outras empresas sob iniciativa e direção governamental. No Brasil, país onde ha tantas industrias a serem tentadas, e que não o são por ser o capital timido, e fugir das empresas arriscadas, e ainda não aprovadas pela experiencia, isto seria mais facil. Darei exemplo. Quem, sinão o govêrno, poderia tentar a cultura da maniçoba? e quem arriscaria capitais em vasta cultura do trigo, quando ha entre nós o espantalho da ferrugem? Mas, preste o leitor muita atenção ao seguinte: a medida de empresas por iniciativas e direção governamental oferece alguns perigos. Quando, como é sabidissimo, Napoleão III atraíu operarios de todas as partes da França para as obras públicas (não rurais, é certo) não contava com a futura derrota de Sedan. Derrotada a França, houve o desespero da multidão desempregada, e, em consequencia deste, a comuna. Não preciso dizer mais sobre a tragedia, muitissimo conhecida... Falo em desocupados: vem-me ao espirito o mais grave de todos os problemas atuais. Supõe ele, para mais facilmente ser enfrentado, uma investigação preliminar: quais os verdadeiros culpados pela miseria em que se encontram? Gide sustenta que a proporção é de $50 \%$. Aqui em São Paulo -- afirmam-me que é de $90 \%$. Que ha infelizes e vadios, nenhuma dúvida, a questão é em relação ao quantum, à percentagem, e à determinação dos que merecem ser socorridos. Deixando esta indagação à polícia, devem os mais altos poderes da nação procurar dar trabalho aos que se acham desocupados: devem agir no suposto de que todos são vítimas de má organisação social.

$O$ recurso de Henrique VIII da Inglaterra, mencionado por Montesquieu, qual o de mandar fechar todos-os asilos, e deixar os suditos morrerem de miseria não é admissivel por todos nós que entendemos ter a sociedade sido instituida para conservação da vida de todos os seus membros. Creio que, em relação às classes votadas aos serviços musculares, vulgarmente denominadas laboriosas, o problema não é de tão dificil solução: obras públicas dirigidas pelo Estado, eis a medida que me parece aceitavel, e muito facil 
de ser adotada, hoje que a estadização de serviços está tão preconizada. Estabelecimento de nucleos rurais, tornar a vida do trabalhador rural menos dura, para se fazer uma realidade o rumo ao campo, dar atenção aos agricultores de pequenas lavouras, como disse eu acima, foram indicações minhas em 1931, pelo "Diário de São Paulo", e felizmente vejo ser este o plano do atual govêrno. Mas o terrivel problema encontra-se relativamente aos intelectuais. O proletário intelectual, com que se ocupam quasi todos os sociólogos e economistas, e deles destacarei GIDE, é o fantasma ameaçador. Note-se que os governantes devem saber que o intelectual desocupado, em desespero, enfurecido pela sorte que Ihe reservou a atual organisação social, é fator importantissimo da subversão, de tremendas revoluções nos Estados organisados pelo sistema que eu denominarei clássico: sistema filho de uma evolução histórica contra a qual pouco se tem feito. É livre de dúvida que a revolução de $1789 \mathrm{~cm}$ França não foi feita pela multidão que tomou a Bastilha, nèm pelos atacantes do palácio de Versalhes, mas sim pela propaganda indefesa de Rousseau, Beaumarchais, Voltaire e outros.

Tem-se comparado o desenvolvimento das revoluções com a incubação do ovo. Durante muito tempo, esta se faz oculta e lentamente, até que, num dado momento, a avezinha bica o envolucro e rompe a casca que a prende: é o simbolo da revolução quando explode, dizem.

Na Russia não foi tão encoberta ou disfarçada a propaganda: dificil era reprimir a manifestação da cólera popular e ocultar a ação dos intelectuais. Embora a censura da imprensa levasse sua cautela até riscar tudo quanto nos livros importados dos paises livres poderia instigar à revolta contra a tirania do czar, apareciam, sem se saber vindos de onde, os panfletos como era o que dizia: "A Russia, oh czar, te havia confiado o poder supremo, e tu eras um verdadeiro deus sobre a terra. E que fizeste? Levaste tua vida a passar revista às tropas, a modificar uniformes, a assinar proje- 
tos legislativos de ignorantes charlatães! Creaste a raça desprezivel dos censores da imprensa, afim de não ouvires a vo $z$ da verdade!..." (IsaAc e Malet, Hist. Cont., pag. 295). O movimento intelectual era, insisto, ostensivo. Assevera o grande sociólogo Pareto que, si a côrte de França, em vez de ter imprudente condescendencia para com os intelectuais, os houvesse, em 1789, castigado rigorosamente, não teria havido a explosão da tomada da Bastilha, etc.

Salvo o respeito devido a tão notavel autoridade em Sociologia, direi que não era possivel maior crueldade do que a que tiveram os reis de França contra a propaganda dos enciclopedistas. Ajuntarei que a Russia é a prova mais eloquente do erro de Pareto.

Verassayefr nos patenteia o que era o espirito público ao tempo em que o czar tiranizava a Russia, quando pretendia o déspota slavo reprimir com o knut a propaganda àos intelectuais. PicArd, Benda e muitos outros dizem que os intelectuais são, em geral, partidarios do despotismo, defensores de atrocidades como é a tortura.

E' possivel que assim seja em relação a um número ínfimo: Hobbes, Ihering e poucos outros. $O$ que se dá na classe culta que é versada, quanto possivel, nos segredos da evolução social, é o temor das reformas súbitas. Sabem, particularmente os jurisconsultos e sociólogos, quanto é perigoso tocar em qualquer instituição, pela repercussão que ha em consequencia do consensus em todos os fenomenos sociais. Apontarei um fato. Quando se iniciou, ha poucos anos, a luta contra o comunismo no Brasil, verificou-se que cerca de $75 \%$ dos medicos eram extremistas, e que rarissimos eram os advogados partidarios das idéias subversivas da ordem social. Creio facil a explicação. Os medicos vêm a miseria das classes menos favorecidas na sociedade atual, e julgam que qualquer medida aconselhada como sendo panacéia, deve ser imediatamente aceita. Os homens que têm conhecimento dos riscos que corre uma sociedade com reformas precipitadas, opõem-se, por prudencia, e não por espirito retrógrado, a tais inovações, temerosos que o remé- 
dio seja peior que o mal. Mas chega de divagações. Que indício para satisfazer os anelos do proletário intelectual? Já na Ordem dos Advogados, onde o problema do excesso de profissionais ocupava a atenção de quasi todos os meus companheiros de Conselho, emití meu parecer que mereceu louvor e apoio nos meios governamentais brasileiros. ("Rev. da Faculdade", v. 31 pag. 220). Sei porém que, aqui, no Brasil, e na Argentina já houve quem propusesse a limitação do número na matricula dos estudantes nas universidades, sistema do czar (Malet, citado pag. 294). Posso assegurar que tambem houve quem pretendesse que todos os moços fossem enviados às oficinas, a martelar nas bigornas, em logar de irem fazer exercicios militares, preparando-se para a defesa da patria.. De martelos, e não de carabinas e de livros necessitam, dizia este czar sulamericano, os rapazes brasileiros.

$\mathrm{Na}$ Ordem dos Advogados, sustentei que os ramos do saber mais uteis hoje em nossa patria eram a eletricidade e a mecanica: altas escolas destes utilissimos estudos pareciam-me indispensaveis mesmo para remediar o excesso de bachareis em Direito. Tive em mente a lei sociológica, de que nos dá notícia Spencer, a saber que os estudos de ciências naturais devem ser os primeiros, seguindo-se então os de ciências filosóficas. Antes de Spencer já o povo dizia, em frase pintoresca: Primo vivere, et deinde philosophare.

Pelas colunas do "Jornal do Comercio" (de São Paulo), ocupei-me, ha muitos anos, com a destruição das nossas riquezas naturais, calamidade que tanta atenção mereceu nos Estados Unidos do Norte e ao Canadá. Fazendo eu menção da piscicultura e da silvicultura, particularmente do reflorestamento das terras descalvadas pelo fogo, fiz sentir que sem técnicos em tais assuntos impossivel seria remediar o mal que tem sido feito, e evitar que prossiga a destruição de riquezas naturais que não são inesgotaveis.

Alonguei-me quiçá desmesuradamente sobre este problema social, já porque o julgo muito premente, já porque é o que conheço melhor por pertencer eu à classe que clama 
por melhorar sua sorte, e que constitue um perigo para a sociedade no momento atual. Não faltam porém outros problemas insoluveis, ou, ao menos, de dificil solução na sociedade. Quero porém referir-me agora aos problemas que tocam mais de perto à Política, porque têm sido objeto de atenção de vários legisladores e administradores.

\section{PROBLEMAS POLfTICOS}

Houve o mais árduo dos problemas que foi o da abolição da escravidão. Foi solvido aqui e nos Estados Unidos de modos diametralmente opostos. Quero com ele, todavia, ocupar-me, para fazer a apologia dos nossos políticos, do visconde do Rio Branco, de Sararva e de outros.

Lincoln solveu violentamente a dificuldade: cortou o nó gordio. Louvores, sem dúvida, merece, mas é certo, dizem os historiadores, que poderia ter conseguido o mesmo resultado sem provocar uma revolução. O que tambem ficou demonstrado, pelo decorrer do tempo, foi terem sido gerados ódios que, até hoje, ha quasi um século, perduram nos Estados Unidos.

Aquí, com a habilidade dos nossos políticos, apoio ao partido abolicionista, várias providencias legais e judiciais, auxilio mesmo dos brasileiros que não pertenciam ao grupo abolicionista, propaganda constante, fez-se a abolição, como tantas vezes tem sido dito, antes que oficialmente tivesse sido decretada em 13 de Maio de 1888.

$\mathrm{Na}$ America do Norte, terminou a negregada instituição numa guerra civil sangrenta, como foi a do secesso, aqui desaparaceu entre festas e foguetes: esses foguetes que ao soberbo BRYce pareciam tão ridiculos... Direi incidentemente, embora sem relação com o assunto que me ocupa neste artigo, muito me admirar não terem o visconde do Rio Branco, Saraiva e outros patriotas brasileiros eternos louvores que são até hoje tributados à memória de Lincoln. Lembrarei outro problema que não tem merecido a atenção 
devida da parte dos nossos politicos: refiro-me à seca do Norte. Fizeram-se estudos valiosos, nos momentos de grandes eștiagens, e tomam-se então momentaneas providencias, mas de definitivo, apenas passado o momento angustioso, só conheço o esfôrço previdente de Epitácio Pessoa. Não basta porém a ação de um politico único, ainda que seja chefe de Estado: é necessario que possa ele contar com a colaboração dos seus compatriotas.

A palavra eloquentissima de EPITÁcı, por um momento abalou a sensibilidade dos brasileiros, e o animou a tomar providescias que infelizmente tiveram de ser abandonadas nos governos seguintes.

Fóra porém o silencio em torno do trabalho do patriota no combate à sêca, ocorre ter eu, não raro, ouvido queixas contra ele por haverem sido abandonadas as obras, e, como era de prever, haverem sido sacrificados milhares de contos no serviço iniciado, como si ao lúcido espirito do presidente de saudosa memoria fosse dado prever o abandono do combate à calamidade. É demais! Aproveito a oportunidade, pois que estou com a pena na mão, não só para render homenagem à memória do grande brasileiro, mas tambem para lembrar ao povo que a sêca, que, desde o século XVII, apavorava nossa Patria, segundo descrições de Porto Seguro e de outros historiadores, tem sua área aumentada anualmente, e ameaça tornar o centro de nossa patria um novo Saara? Repito porém: é necessario que haja um movimento popular em pról de luta contra essa fatal e sinistra ameaça para que possam os politicos fazer qualquer coisa em beneficio de nossa Patria: o politico, direi mais uma vez, nada póde fazer a não ser dirigir forças que se lhe deparam no corpo social, ou que ele faz desenvolverem-se no organismo social, como incubou o visconde do Rio Branco as tendencias de nosso povo ao horror à escravidão. $O$ chefe está longe de ter a onipotencia, que lhe atribue o vulgo. Fatos de pouca importancia se mostram na sociedade, direi, ocupando-me com outra matéria, sem nenhuma explicação plausivel, e 
razão teve LEon DonNaT (cuja obra infelizmente viveu tanto quanto a rosa de Malherbes) de dar tanta importancia à Politica Experimental: toda lei tem sempre o carater de uma experiencia. Seja-me permitido recordar um fato que é de meu estagio nas lides forenses. Quando se procurou estabelecer em 1864, o regime de registro hipotecario e imobiliario, levantou-se um grande clamor, dizendo-se que a instituição era só possivel em França, e que fôra erro grave procurar introduzíla no Brasil. Os fatos porém (posteri dies testes sunt sapientissimi) desmentiram essa profecia. Quando, mais tarde, se tentou implantar o sistema Torrens no serviço de registo de imoveis, todos os homens cultos cantaram hinos em favor da novidade: a Lei Torrens, ficou contudo sendo letra morta no Brasil...

Que explicação dar? Não basta dizer, como se tem dito, que foi a Lei Torrens mal adatada à nossa Patria, porque sumamente complicada em suas particularidades, particularidades regulamentares que foram aparecendo no seu país de origem, à medida que eram reclamadas pela prática: é franca tal explicação. Pouco devo dizer sobre os problemas do número de horas de trabalho e aposentação dos trabalhadores. A materia tem sido tão discutida e esclarecida pelos interessados nos beneficios das citadas reformas que só me resta mostrar com quanto tato devem ser feitas as reformas. A diminuição de uma hora de serviço em todos os estabelecimentos, si não ha superprodução, traz uma acentuada alta no preço do produto, dando prejuizo para as proprias classes que pretenderam ser favorecidas. Mas, si ha superprodução, nenhum mal advem dessa medida humana e simpática a todos que compreendem que a sociedade não se fez para sacrificio de uma numerosa classe. Sobrevém uma guerra como acaba de suceder. Indispensavel se torna aumento de horas de trabálho. Até aí nenhuma novidade: mas de quanto deve ser o aumento exigido pelo governo, quanto é indispensavel para salvar-se a Patria, eis o problema que exige muito tato. 
A aposentação é instituto muito desejavel: nada mais justo do que o repouso dos velhos que dedicaram sua vida aos serviços úteis à Patria. Mas qual a idade em que deve ser dada? Deve ser compulsoria em relação aos empregados públicos. Em que fórma deve ser reservado o capital, o fundo necessario para fazer face às despesas com essa classe de inativos? Quanto a esta última questão, sabido é que, em França, houve tentativas diversas. Obrigar a classe a reservar peculio para os velhos e invalidos, foi coisa contraria ao egoísmo dos trabalhadores (Dalloz, Retraite, ns. 168 e s.). Na Ordem dos Advogados, tive ocasião de ver quanto era dificil o problema de formar um fundo de socorro para os infelizes da classe. A idéia que prevaleceu não foi de um único membro do Conselho, mas de diversos: o instituto é filho de varios pais. Os problemas relativos à assistencia social são já muito conhecidos, autorizando-me pois a passar a outros. Lembrarei todavia que, em congresso reunido na Argentina, ha alguns anos, apareceu a pergunta "si era melhor entregar a particulares, si ao Estado o serviço". Pareceu-me que a melhor solução era a de confiar a administração aos particulares, e a fiscalização ao Estado. Bem sei quanto foi falha essa fiscalização, quer pelas autoridades administrativas, quer pelas judiciárias, pelo Juizo da Provedoria, Residuos e Capelas. Com risco de ser acoimado de transformar este meu artigo em colcha de retalhos, ocupar-me-ei com um problema de Criminologia. Porque será que, quando ha excessivo aumento ou extraordinária diminuição da população de uma localidade, ha exagero tambem no indice da criminalidade, mas em proporção muito maior que a mudança da cifra demográfica? Exemplificarei para tornar de mais facil compreensão a questão posta pelos Criminologistas. Se dobra a população de um centro populoso, a criminalidade cresce em muito mais que o dobro. Si diminue além do normal, tam'bem ha aumento de delitos, proporcionalmente ao indice anterior... $O$ que se deveria esperar era que o número de crimes acompanhasse matematicamente a variação do 
número de habitantes. Se o fenômeno é inexplicavel, resta: porém a medida mitigatoria de evitar um excesso, quer na emigração, quer na imigração. Neste caso, como em tantos outros, devemos nos contentar com medidas empiricas.

Não quero deixar a pena, pingando o ponto final neste fertilissimo terreno de problemas sociais, sem fazer referencia ao conhecidissimo de acidentes do trabalho: não o deixarei esquecido. Andou-se nele às apalpadelas. Começando-se por lançar a responsabilidade ao patrão (risco de negocio), passou-se a permitir a transferencia da responsabilidade a um grupo segurador, organizando-se afinal as companhias de seguros, sob a fiscalização do Estado, etc. Quando estava adeantada a solução da dificuldade, eis que aparece o embaraço acerca da maneira de pagamento. Notou-se que as famílias que recebiam a indenização pouco depois gastavam tudo, e caíam na mais negra miseria, resultado de sua imprevidencia. Foi então adotada a salutar medida do pagamento em prestações ou mensalidades: renda vitalicia. Creio que poderia eu encher volumes, mostrando que governar não é tão facil quanto geralmente julga o vulgo ignorante. Ha uma lenda oriental favoravel ao regime despótico, ou do bom déspota: é absurda, como passo a mostrar. Refere o conto que uma pobre mulher procurou um sultão para se queixar de que fora furtada em suas parcas economias, enquanto dormia debaixo de uma árvore. "Dormias pois profundamente, observou o brutal monarca, porque não percebeste que estavas sendo furtada". "Senhor, revidou a mulher, eu dormia tranquila e profundamente confiada em que vossa magestade velava pelos seus suditos." Retorquiu o sultão: "Volta a dormir sob a mesma arvore, e quando acordares, verás as providencias que eu dei." Ao despertar, encontrou a mulher de um lado sua modesta bolsa com as economias que lhe haviam sido furtadas, e viu enforcado nos galhos da arvore o ladrão. Este conto, produto de louvaminheiros do sórdido déspota, cuja idéa fixa é a guarda de seu harem, é tudo quanto ha de menos verosimil. Ha o caso análogo de que nos dá noticia a His- 
toria, e é o do Tratado de Santo Ildefonso, obra do inepto marquês de Pombal, que a ninguem ouvia nem consultava. Quando este repulsivo monstro recebeu do efeminado rei português as rédeas do govêrno, fez o péssimo tratado de cuja responsabilidade querem seus partidarios o eximir. A critica historica, porém, que é inexoravel, mostrou que foi só o marquês, o ignorante e feroz ministro, o único responsavel pelo desastre. Quem poderá acreditar que um rude sultão, metido em seu serralho, rodeado de aduladores, possa ter escolha de técnico em medidas policiais? Quem, em bôa fé, dirá que a nossa policia cientifica dê menos resultado que o de um brutal chefe oriental? Ereciso que se acabe, de uma vez por todas, com essa lenda (não oriental, mas de todos os ignorantes ou bajuladores) do bom déspota. A Abrir escolas onde se estude o organismo social em sua complexidade, como se estuda o organismo animal nas de Biologia, diminuir, quanto possivel, o campo do desconhecido em matéria governamental, buscar, embora sem esperança de inteira ou completa vitória, que não mais se deva dizer "o organismo humano, esse desconhecido", é o que me parece dar bom andamento à vida de uma sociedade em pleno desenvolvimento. Fique o sistema de governar brutalmente para os povos bárbaros, semi barbaros e selvagens, enquanto não entrarem no caminho da civilização.

\section{ACERCA DE TÉCNICOS}

Tenho no desenvolver de minhas idéias, neste artigo falado várias vezes em técnicos. Cumpre-me dar ao leitor um esclarecimento para firmar a que profissionais eu me refiro. Sempre tivemos técnicos assistindo, assessorando, ou auxiliando os administradores. Mencionarei o antigo Conselho de Estado e os consultores juridicos a serviço de repartições públicas. Eram porém de funções limitadas a um ramo único: materia juridica. Foram, e são utilissimos em um Estado de desenvolvida cultura como é o Brasil. 
Devem, creio eu, ser mantidos os consultores que hoje prestam relevantes serviços.

Na memoria porém que eu apresentei à Ordem dos Advogados, eu me referi a técnicos versados em materia de mecânica ou de eletricidade.

Nos meus artigos publicados no "Jornal do Comercio", eu pedi a ação de versados em Silvicultura e Piscicultura. Si o Brasil necessita hoje de silvicultores, de eletricistas, de piscicultores, de versadissimos em mecânica, inegavel é que não póde dispensar tambem os juristas. Para mostrarem os sociólogos como ha o desenvolvimento harmonico em um país, fazem comparação com a cultura romana, e dizem que, na cidade marmórea dos Cesares, havia tambem a choupana de Romulo.

Critico sómente que o desenvolvimento filosófico tenha sido em prejuizo do utilissimo material.

\section{FINALIZANDO}

Terminando este meu já longo artigo, direi que não procurei resolver nenhum dos mais altos problemas sociais, antes timbrei em mencioná-los, expô-los, mostrando quão dificil é encontrar a solução a dar-lhes, quando soluveis. Aconselhei experimentalmente medidas empíricas paliativas ou mitigatorias. Asseverei que, quando remedíados em parte, ficarão porém alguns eternamente insoluveis. Não nego porém que o número desses problemas irá diminuindo, assim como, segundo os médicos, tem diminuido o número das molestias meramente nervosas, ou molestias imaginarias: a cultura na Sociologia, do mesmo modo que na Medicina, reserva-nos surpresas. Em suma: problemas insoluveis, de dificil solução e que não têm sido solvidos em consequencia de não terem sobre eles operado técnicos de valor. 


\section{UMA NOTA SUPLEMENTAR}

Manda a justiça que eu consigne ter o atual govêrno feito em beneficio dos operarios do Brasil o que não tinha sido feito por nenhum de seus predecessores. A legislação social brasileira, obra recente, filha do movimento de $\mathbf{1 9 3 0 ,}$ é uma das mais adeantadas do mundo, sem os exageros da ditadura proletaria da Russia. Para sua leal execução foram creados os tribunais adequados a solver os pleitos entre os patrões e os operarios. Escolas onde são estudados alguns dos problemas com que acabo de ocupar-me estão funcionando, e mostram aos que se encontram nelas quanto é de valor conhecer o organismo social, no que este tem de cognoscivel, e patentear que ha muito nele acima das forças da mente humana. Fez o governo, ouvindo os competentes, tudo quanto era humanamente possivel para satisfazer anelos dos trabalhadores. A prova mais segura de quão proveitoso tem sido o rumo tomado em nossa patria desde 1930 foi que se conseguiu acabar com as paredes de operarios, fazer calar quantos se batiam pelas idéias comunistas, e dar tranquilidade ao povo brasileiro. No momento em que escrevo estas derradeiras observações (5 de junho), dá-nos o telégrafo a notícia de que, nas Ilhas Bahama, ha revolta de operarios, que pedem aumento de salario, e, famélicos, invadem os armazens de comestiveis.

Já estavam escritas as últimas palavras deste artigo, quando foi publicado o Decreto Lei de 6 de Junho corrente, que mostra com quanto cuidado está o Govêrno aperfeiçoando a legislação relativa ao trabalho. É esse Decreto Lei a confirmação do que eu disse, linhas acima: toda lei tem sempre o cunho, ou carater de uma experiencia. 